\title{
Maritim Culture Literacy Acquisition in Early Childhood (Case Study in Kepulauan Seribu, Indonesia)
}

\author{
Hapidin $^{1}$, Nubiana Dhieni ${ }^{2}$, Yuli Pujianti ${ }^{3}$, Suharti ${ }^{4}$, Sofia Hartati ${ }^{5}$ \\ \{hapidin@unj.ac.id ${ }^{1}$, cucu.suharti249@gmail.com $\}$ \\ Universitas Negeri Jakarta, Jl. Rawa Mangun Muka Raya No.11, RT.11/RW.14, Rawamangun, Kec. \\ Pulo Gadung, Kota Jakarta Timur, Daerah Khusus Ibukota Jakarta 13220 1,2,5 \\ STIT Al Marhalah Al Ulya Bekasi, Jl. KH Mas Mansyur No.30, RT.007/RW.002, Bekasi Jaya, Kec. \\ Bekasi Tim., Kota Bks, Jawa Barat 17112
}

\begin{abstract}
This study aims to investigate and explore the acquisition of maritime culture literacy in early childhood. This study used a qualitative case study approach with four early childhood participants aged 4-7 years using semi-structured interviews and observation methods. The findings of this study have demonstrated that the acquisition of maritime culture literacy in early childhood through social interaction with peers and adults, through natural play, and providing support through scaffolding) from adults, especially parents around children. The maritime culture literacy acquisition by children includes (1) maritime knowledge such as coastal and marine ecosystems, the lifestyle of fishing communities and natural phenomena that occur, (2) attitudes to life and the maritime environment, and (3) living habits in a maritime environment.
\end{abstract}

Keywords: maritime cultural literacy, cultural literacy, natural Play, culture maritime acquisition, early childhood.

\section{Introduction}

Maritime culture literacy is part of cultural literacy. The cultural literacy of a society becomes a reference for measuring the competitiveness of that community. As an important issue, maritime culture literacy is often placed as a central issue in a country's policy in building social life and human resource development through education. Maritime culture has consequently become ingrained in the daily lives of those who work or live near the sea, whether as a fisherman or in other jobs related to the distribution and processing of marine products [1]. The one of a worthy goal of education is improve culturally literate knowledge and appropriate attitudes that oftentimes cultural literacy interpreted a particular form of aesthetic literacy tends exclusionary. Cultural literacy is a focused activity and critical attitude whereby one becomes conscious of take for-granted values, attitudes, and beliefs of one's own and other cultural systems.[2] Maritime literacy by UNESCO is declared as ocean literacy. The essential principles of ocean literacy are that the Earth has one large ocean with many features, that the ocean and life in the ocean shape the features of the Earth, that the ocean is a major influence on weather and climate, that the ocean makes the Earth habitable, that the ocean supports a great diversity of life and ecosystems, that the ocean and humans are inextricably linked, and that the ocean is largely unexplored [3] 
Maritime culture literacy refers to the knowledge, values, attitudes, and skills of individuals in understanding, organizing, and using knowledge, values, and various experiences to solve problems in life in a maritime cultural environment. Maritime culture literacy includes skills in self-organization, social interaction skills, job skills, and academic skills. Cultural literacy is not only purpose to mastering the skills needed at present but also the skills needed and demanded in the next century, especially the 21 st century. A number of 21 st-century skills need to be built from early childhood, such as communication skills, critical and creative thinking skills, skills collaborating and problem-solving skills.

The development of cultural values and maritime social system repository, improving ocean and culture literacy, harmonizing local wisdom in sustainable resources, historic seaport revitalization, reviving the understanding of maritime culture, and innovation based on local wisdom development are among the six main programs of Indonesian Ocean Policy [4]. So maritime culture literacy, which refers to the various contexts faced by individuals in which they live and the cultural institutions that surround it, need to be controlled by the people of Indonesia as a maritime [5]. Early childhood is part of society and naturally learns through a process of imitation of the environment. Maritime culture literacy is a literacy that needs to be introduced to early childhood. The introduction of maritime culture literacy in early childhood is closely related to acquiring maritime culture literacy. The differences in ecological and cultural environments will have an impact on the types and content of cultural literacy needed and obtained by children. Likewise, early childhood children who are born, live, and raised in a maritime environment they have a need to master maritime culture literacy. Maritime culture literacy, in general, can be taught through various educational settings in families, communities, and schools. Maritime culture literacy is very important because it provides a context for getting to know maritime culture as a culture that is very close to early childhood living in coastal areas and to overcome social problems in the maritime area. Children born and raised on the island, their daily activities are in the maritime environment. Viewed from the cultural aspect, naturally, early childhood carry out daily activities based on the maritime culture that is inherent in them. Therefore, maritime culture literacy, specifically in early childhood living on islands, will be meaningful if it is by the context of the island environment or the environment surrounded by the sea.

Maritime culture that includes not only traditions but also navigation, all the activities related to the sea, an original perspective for an in depth understanding of coastal cities, over and above the traditional approaches [6]. Maritime culture literacy is related to the skills to recognize, understand and process data, information or information relating to conditions and various aspects of maritime life [6]. Literacy has a meaning that extends beyond the ability to read and understand but leads to more intelligent information processing skills [7], [8]. This meaning provides something different from the understanding of cultural literacy, which emphasizes the process of cultural literacy.

Maritime culture literacy is one of the root problems and, at the same time, a focus on developing maritime culture in the generation of the Indonesian nation. Maritime culture literacy, as an effort to improve maritime culture in Indonesia, must start from early childhood because early childhood is the next generation of the maritime nation. After colonialism, the Indonesian nation's awareness of itself as a marine nation diminished. This state of affairs still exists. Maritime culture literacy is achieved by constructing various types of factual, conceptual, procedural, and metacognitive knowledge about Indonesian maritime life, as defined by the Bank (2006) as knowledge construction, in which the cultural communities in which individuals are socialized are also epistemological communities with shared beliefs, perspectives, and knowledge [9]. The fading of the awareness as a maritime nation then has an 
impact on the realm of values in maritime culture that has begun to fade in the life of Indonesian people, especially the island community or fishing community. According to the finding previous research that there is a change in the orientation of the life of the fishing community from marine life to the land [10]. Also, attitudes and behavior as a cultured maritime society have undergone a shift, both in the context of everyday people's lives and in the context of education. The various problems faced by the Indonesian nation as a maritime nation must be resolved through the introduction of maritime culture literacy. This study investigates and explores maritime culture literacy in early childhood.

\section{Method}

This research uses a qualitative approach. Specifically, the case study was chosen by the researcher because it could explore the data more deeply as well as to understand the participants. The focus of this research is to explore the acquisition of maritime culture literacy in early childhood, especially those living on islands. Participants in this study were randomly selected, namely four early childhood children aged 4-7 years who live on the island of Untung Jawa, one of the islands in the Thousand Islands. Data collection was carried out through interviews and participatory observation. Interviews were conducted by researchers informally when children were playing on the beach. Meanwhile, participatory observation is carried out by researchers directly when interacting with participants. This research procedure includes the stages of data collection, data recording, coding, data analysis, and data interpretation. At the data collection stage, researchers conducted interviews using recordings on cellphones and recorded them in field notes. Then the recording is transferred to the computer. Researchers listen again to the recording to be matched with the field notes that have been made. The observed data obtained were also recorded in field notes. Field notes from interviews and observations, then the researcher coded the data. The data coding was then carried out by an analysis of Campbell's matchmaking pattern, which consisted of 3 main stages, namely the preparation of a general statement, the selection of a special statement, and the development of a concept map. [11]. In the final stage, an interpretation of the results of the data analysis.

\section{Findings and Discussion}

\subsection{Social interaction as apicenter of maritime culture acquisition}

The process of social interaction in early childhood with peers and adults is the main epicenter in maritime culture literacy acquisition. Early childhood acquire maritime culture literacy through the process of social interaction with peers through various activities, tools, and learning resources from the environment around maritime life, because he ability to effectively begin and maintain social interaction with others while avoiding incorrect social behavior is referred to as social interaction. [12]. The activities of social interaction which are usually catching or fishing, processing shells into toys, building boats, looking for shells, looking for sea turtles, swimming and playing with sand. 
"At first, I could not be fishing, but when I played with my friends, then invited me to fish on the dock. My friend tells me how to hook fish-besides that, taught by my father. On Sundays or holidays, my father invited him to catch fish by boat while being introduced to seawater currents, tidal waves, sea breezes, and caught fish. Because my father and friends often invited me to fish, finally I was able to be fishing” (Interview N)

"For me, I was afraid to swim at the beach. My friends always ask me to swim. My friends pulled me, so I wanted to swim. Finally, now I can swim and am not afraid to swim on the beach anymore (Interview $U$ )

Children and their peers collect shells on the beach to play together while playing in the sand. They interact with each other, tell each other about the activities they do. Other activities were children looking for shells and seagrass on the beach. The clams and seaweed they collect are then cooked by one of their mothers and eaten together. Children were able to describe the characteristics of each type of fish and grass they got (Field notes 1)

The process of social interaction that builds early childhood maritime culture literacy occurs in interactional situations with peers during school through playing at school, after school, and during school holidays on Saturdays or Sundays. Social interaction one of a type of play that activities in which they engage are thus incidental to their need for group association and enables more effective resource exchange [13], [14]. Maritime culture literacy as part of literacy involves cognitive processes [15]. The social interaction context would allow children a cognitive benefit [16]. Places that are usually in social interaction are beaches, mangrove forests, docks, ground, and gazebo places to gather. Children in the marine environment carry out social interactions. The marine environment for people living on the island is a public place where they usually interact because public places can support social interaction. [17].

\subsection{Natural play gives a dominant role in maritime culture literacy acquisition}

The findings of this study found that natural play is the main way for early childhood to interact socially and share knowledge, attitudes, and behaviors related to mastery of maritime culture literacy. Playing is described as a variety of activities and behaviors that children engage in [18], [19]. In early childhood, they love to play and naturally carry out various activities through play, because play is pleasurable, enjoyable, entertaining, self-directed, and intrinsically driven [18], [20].

"I played with my friends on the beach. In the sea, much fish, including pufferfish, stingrays, starfish, and others" (Interview Y)

Children play together with their friends on the beach. They play sand, play hide and seek, play romp, and so children play together with their friends on the beach. They play sand, play hide and seek, play romp, and so on (Field notes, 2)

Based on interviews regarding natural play activities carried out by them, it shows that natural play occurs in early childhood in various contexts of place, situation, or event and time. 
Natural play activities are carried out by using places that change and move. There are such as from the beach location to gazebo, from fishing to shifting to looking for kerrang, natural play activities can be done in the morning, afternoon, and evening using various objects or goods that are found around the coastal environment and its surroundings. Children play by taking advantage of the natural environment around the beach. Through their participation, the natural environment for play has been enhanced [21] and is the importance of for the child's development [22]. Natural play in early childhood will help child development. Children explore the natural environment of the beach while playing with their friends, which naturally develops aspects of their development. Risky outdoor play in the style of natural play [23] influenced and had good effects on a child's development [22], [24]. When children doing the natural play in a beach environment, the children build a relationship with the natural environment around them. Nature play can be a powerful way for children to engage with the natural world [25]. Natural play sometimes carries out doing various traditional island children's games. By doing natural play activities, children can provide the opportunity to freely express themselves and develop their abilities without feeling tired or embarrassed by adults, and Nature play provides more open-ended chances for movement, affordances, and the development of social and problem-solving skills. [26].

\subsection{Scaffolding from parents support maritime culture literacy acquisition}

Parental support has an important role in providing an intervention to help early childhood acquire diverse maritime culture literacy. The process of providing assistance to youngsters in order to help them overcome difficulties beyond their current skills or attain a goal that would be impossible for them to achieve on their own [27], [28] and a significant influence on the form of parental scaffolding [29], [30].

"My father taught me how to be fishing, for example, find out bait to fish and how to hook the hook. Father also told me that fish are dangerous and not, including telling me that sea urchins can sting and cause itching. " (Interview U)

"Mother told me if the shells are still alive, their shells will be closed, but when my mother cooks the shells, the shells will open. Mother also told me about the types of fish that were edible and which could not eat. My mother said to me if the shells are still alive, their shells will be closed, but when cooked, the shells will open. Mother also told them what kinds of fish were edible and which were not" (Interview I)

"My father and mother taught me to become tour guides for tourists. I was following when Mom or Dad were guiding tourists, after finishing driving then Mom or Dad explained how to tour guide (wawancara $U$ )

These interviews indicated that parental support in the form of scaffolding helped them to understand maritime culture literacy. Parental support is carried out by giving examples and teaching children directly in mastering maritime culture literacy, such as using a hook and hooking a fishing line, choosing the type of bait, looking for types of shellfish, identifying dangerous fish, and looking for edible types of seagrass. Parents provide skills of maritime culture literacy by scaffolding with giving support to children so that they can be 
mastered independently without help gradually. For example, when teaching fishing, at first, the child only sees the parent putting the bait on the hook; the next stage, the child begins to learn to put the bait on the hook with the help of the parent; until the final step, the child can put the bait on the hook themselves without help from the parents. Parental scaffolding may help children transfer skills learned from parent-child interactions, as well as parents develop more developmentally sensitive approaches to similar independent problem-solving contexts, as the child practices solving the problem alone to the greatest extent possible when the adult shifts the level of support according to the child's performance [31], [32].

\section{Conclusion}

Maritime culture literacy acquisition occurs through a process of early childhood social interaction in various times, places, and contexts of events. Also, natural play is the best event and experience for children to know and learn various types of maritime culture literacy. In natural play, children share knowledge, tools, and ways of playing, which contain a lot of maritime culture literacy content. Strengthening the acquisition of maritime culture literacy is also provided by adults through scaffolding in the form of giving examples in recognizing, understanding, and demonstrating specific skills concerning maritime culture. In conclusion, maritime culture literacy in early childhood based on the process of social interaction, natural play, and scaffolding from parents, namely skills to know and understand sea conditions such as ocean currents and winds, tidal waves, the dangers of several types of animals; the skills of baiting a hook, using fishing gear, and fishing by various techniques; identify types of marine animals and grasses which are edible and which are dangerous for consumption; communicate well to be a tour guide for tourists. These findings suggest that do more future research to explore the specific maritime culture literacy in other contexts and cultures.

Acknowledgments. We would like to thank to Early Childhood Education Departement Universitas Negeri Jakarta, MESI (Marine Education Study in Indonesia), and the Head of Untung Jawa Island. 


\section{References}

[1] K. B. Prasetyo, Gunawan, and Fajar, "Maritime Culture Literacy on the Children of Pantura Fishermen Using the Media of Art: The Case Study at Banyutowo Village, Central Java," in International Conference on Social Sciences and Interdisciplinary Studies, 2019, vol. 208, no. Icssis 2018, pp. 92-96.

[2] K. A. Hamblen, "Beyond the Aesthetic of Cash-Culture Literacy," Stud. Art Educ., vol. 31, no. 4, pp. 216-225, 1990.

[3] UNESCO, Ocean Literacy for All. Paris: UNESCO, 2017.

[4] T. R. Adi, "Maritime Culture Empowerment under Indonesian Ocean Policy," J. Ocean Cult., vol. 1, pp. 102-117, 2018.

[5] Lbk/Mhf, "Indonesia , A Land-Oriented Maritime Country," Nusantara Maritime News, 2014. [Online]. Available: https://maritimenews.id/indonesia-a-land-orientedmaritime-country. [Accessed: 05-Sep-2020]

[6] M.-P. A. O. S. Clemente M. Esposito De Vita G., "Maritime culture and urban culture in Mediterranean cities: Barcelona, Marseille, Valencia, Naples," Proc. Int. Conf. Med.Net.Eu.12, no. January, 2014.

[7] J. Arthur, "Cultural Literacy," Coll. English, vol. 52, no. 3, p. 281, 1990.

[8] E. Hirsch Jr, "Restoring cultural literacy in the early grades," Educ. Leadersh., vol. 45, no. 4, 1987.

[9] J. A. Banks, Race, Culture, and Education. Routledge, Taylor and Francis, 2006.

[10] Hapidin, Nurjannah, and S. Hartati, "Pengembangan Model Pembelajaran Tematik Integratif berbasis proyek dalam menerapkan pendidikan kelautan pada anak di Kepulauan Seribu," J. Pendidik. Usia Dini, vol. 12, no. 1, pp. 51-65, 2018.

[11] Robert K. Yin, Case Study Research Design and Methods, 5th ed. London, India: SAGE Publications, 2003.

[12] J. Sigafoos, V. A. Green, D. Payne, S. H. Son, M. O’Reilly, and G. E. Lancioni, “A comparison of picture exchange and speech-generating devices: Acquisition, preference, and effects on social interaction," AAC Augment. Altern. Commun., vol. 25, no. 2, pp. 99-109, 2009.

[13] R. Crandall, "Social Interaction, Affect and Leisure," J. Leis. Res., vol. 11, no. 3, pp. 165-181, 1979.

[14] J. Nahapiet and S. Ghoshal, "Social capital, intellectual capital, and the organizational advantage," Acad. Manag. Rev., vol. 23, no. 2, pp. 119-158, 1998.

[15] L. Hejsek, K. Kopecky, J. Kusa, M. Polak, and H. Maresova, "Literacy In Relation To Cognitive Theories And Models Of Information Processing Dr.," in International Multidisciplinary Scientific Conferences on Social Sciences and Arts, 2015.

[16] P. Fernández-Berrocal and C. Santamaría, "Mental models in social interaction," J. Exp. Educ., vol. 74, no. 3, pp. 227-248, 2006.

[17] N. Ujang, M. Kozlowski, and S. Maulan, "Linking place attachment and social 
interaction: towards meaningful public places," J. Place Manag. Dev., vol. 11, no. 1, pp. 115-129, 2018.

[18] J. Lindon, What is play? London: Children's Play Information Service, 2002.

[19] A. D. Pellegrini, "Research and policy on children's play," Child Dev. Perspect., vol. 3, no. 2, pp. 131-136, 2009.

[20] S. Powell, "The value of play: constrictions of play in government policy in England," Child. Soc., vol. 23, no. 1, pp. 29-42, 2009.

[21] N. D. Ridgers, Z. R. Knowles, and J. Sayers, "Encouraging play in the natural environment: A child-focused case study of Forest School," Child. Geogr., vol. 10, no. 1, pp. 49-65, 2012.

[22] A. Luchs and M. Fikus, "A comparative study of active play on differently designed playgrounds," J. Adventure Educ. Outdoor Learn., vol. 13, no. 3, pp. 206-222, 2013.

[23] L. N. Tink, B. C. Kingsley, N. Spencer-Cavaliere, E. Halpenny, M. A. Rintoul, and A. Pratley, "Pushing the outdoor play agenda': exploring how practitioners conceptualise and operationalise nature play in a Canadian context," Qual. Res. Sport. Exerc. Heal., pp. 1-16, 2018.

[24] T. Ward, S. Goldingay, and J. Parson, "Evaluating a supported nature play programme, parents' perspectives," Early Child Dev. Care, pp. 270-283, 2017.

[25] J. Ernst, "Zoos' and Aquariums' Impact and Influence on Connecting Families to Nature: An Evaluation of the Nature Play Begins at Your Zoo \& Aquarium Program," Visit. Stud., vol. 21, no. 2, pp. 232-259, 2018.

[26] E. J. Murray and P. H. Williams, "Risk-tasking and Assessment in Toddlers During Nature Play:The Role of Family and Play Context," J. Adventure Educ. Outdoor Learn., 2019.

[27] D. Wood, J. S. Bruner, and G. Ross, "The Role of Tutoring in Problem Solving," J. Child Psychol. Psychiatry, vol. 17, no. 2, pp. 89-100, 1976.

[28] M. B. Bibok, J. I. M. Carpendale, and U. Müller, "Core Competencies and the Prevention of High-Risk Sexual Behavior," New Dir. Child Adolesc. Dev., vol. 123, pp. 17-34, 2009.

[29] D. B. Conner and D. R. Cross, "Longitudinal analysis of the presence, efficacy and stability of maternal scaffolding during informal problem-solving interactions," $\mathrm{Br}$. $J$. Dev. Psychol., vol. 21, no. 3, pp. 315-334, 2003.

[30] C. Fair, M. Vandermaas-Peeler, R. Beaudry, and J. Dew, "'I learned how little kids think': Thirdgraders' scaffolding of craft activities with preschoolers," Early Child Dev. Care, vol. 175, no. 3, pp. 229-241, 2005.

[31] R. Clark, R. Menna, and W. S. Manel, “Maternal scaffolding and children's social skills: a comparison between aggressive preschoolers and non-aggressive preschoolers," Early Child Dev. Care, vol. 183, no. 5, pp. 707-725, 2013.

[32] J. Sun and Y. Tang, "Maternal scaffolding strategies and early development of selfregulation in Chinese preschoolers," Early Child Dev. Care, pp. 1525-1537, 2017. 